\title{
FUNGSI SENTRA PENEGAKAN HUKUM TERPADU (GAKKUMDU) DALAM PENEGAKAN HUKUM TINDAK PIDANA PEMILU TAHUN 2019 DI KABUPATEN CIANJUR
}

\author{
Budi Nuryanto \\ Dtr Reskrim Umum Polda Jabar \\ E-mail:budinuryanto73@yahoo.com
}

Pemilihan yang dilakukan di Indonesia, dalam penyelenggaraannya, terdapat banyak permasalahan dan pelanggaran. Permasalahan permasalahan tersebut tentunya perlu adanya penyelesaian dari pihak-pihak yang harus bertanggung jawab secara professional, yaitu dengan adanya Sentra Penegakan Hukum Terpadu (GAKKUMDU). Sentra Penegakan Hukum Terpadu, adalah fonum yang dibentuk guna untuk menangani pelanggaran secara cepat. Sentra Penegakan Hukum Terpadu adalah Forum Badan Pengawas Pemilu/Panitia Pengawas Pemilu, Polri dan Kejaksaan di tiap angkatan yang dibentuk sejak Pemilu Tahun 2004. Metode Penelitian yang digunakan adalah yuridis normatif, yaitu penelitian hukum yang dilakukan dengan cara meneliti bahan pustaka atau data sekunder sebagai bahan dasar untuk diteliti dengan cara mengadakan penelusuran terhadap peraturan-peraturan dan literature-literatur yang berkaitan dengan permasalahan yang diteliti. Sentra Penegakan Hukum Terpadu (GAKKUMDU), dibentuk guna mengefektifkan koordinasi antara institusi yang terlibat dalam penanganan pelanggaran maupun kejahatan dalam tahap tahapan Pemilu. Sentra Penegakan Hukum Terpadu Kabupaten Cianjur dalam kerangka Penegakan Hukum Pidana Tindak Pidana Pemilu guna memberikan kepastian hukum bagi masyarakat.

Kata Kunci : Pemilihan; Penegakan; Pidana; Terpadu.

\section{ABSTRACT}

Elections conducted in Indonesia, in the implementation, there are many problems and violations. These problems certainly need to have a settlement from the parties that must be responsible professionally, namely by the existence of The Integrated Law Enforcement Center, is a forum formed in order to deal with violations quickly. The center for Integrated Law Enforcementmi The Election Supenvisory Board Forum/Election Supervisory Committee, the National Police and The Prosecutor's office in each force, established since the 2004 Elections. A bases for research by conducting a search of the rules and literature relating to the problem under study. The Integrated Law Enforcement Center (GAKKUMDU) was formed to make coordination between institutions involved in handling violations and crime both in stages and in the elections process. Integrated Law Enforcement Center Kabupaten Cianjur in the framework of Election Criminal Law Enforcement in order to provide legal certainty for the community.

Keywords $\quad$ : Election; Enforcement; Criminal; Integrated. 


\section{A. PENDAHULUAN}

Indonesia sebagai Negara Hukum yang demokratis merupakan pernyataan politik hukum yang tercermin dalam Undang-Undang Dasar 1945 Pasal 1 ayat (1) yang menyatakan bahwa "Negara Indonesia ialah Negara Kesatuan yang berbentuk Republik", dan ayat (2) menegaskan bahwa "Kedaulatan berada di tangan rakyat dan dilaksanakan menurut Undang-Undang Dasar", sedangkan ayat (3) yang berbunyi "Negara Indonesia adalah Negara Hukum" (Mulyadi, 2012). Indonesia adalah salah satu negara di dunia yang menerapkan Sistem Politik Demokrasi. Demokrasi di Indonesia ini memiliki sebuah slogan yang cukup singkat, yakni "Dari Rakyat, Oleh Rakyat Dan Untuk Rakyat". Demokrasi yang diterapkan di Indonesia adalah demokrasi keterwakilan, dimana salah satu contoh pengejawantahan daripada demokrasi ini adalah adanya pesta demokrasi, yaitu Pemilihan Umum (Pemilu).

Di Indonesia, Pemilihan Umum menurut Miriam Budiarjo merupaka penafsiran normative dari Undang-Undang Dasar Negara Republik Indonesia Tahun 1945 agar pencapaian masyarakat mungkin tercipta. Masyarakat demokratis ini merupakan penafsiran dari pelaksanaan kedaulatan rakyat. Undang-Undang Dasar 1945 dalam Pasal 22E, menyebutkan bahwa :

1. Pemilihan Umum dilaksanakan secara langsung, umum, bebas, rahasia, jujur dan adil setiap lima tahun sekali;

2. PemilihanUmum diselenggarakan untuk memilih anggota Dewan Perwakilan Rakyat, Dewan Perwakilan Rakyat Daerah, Presiden dan Wakil Presiden dan Dewan Perwakilan Rakyat Daerah;

3. Peserta Pemilihan Umum guna memilih anggota Dewan Perwakilan Rakyat dan anggota Dewan Perwakilan Rakyat Daerah adalah Partai Politik;

4. Peserta Pemilihan Umum guna memilih anggota Dewan Perwakilan Daerah adalah perseorangan;

5. Pemilihan Umum diselenggarakan oleh suatu komisi pemilihan umum yang bersifat nasional, tetap dan mandiri;

6. Ketentuan lebih lanjut tentang pemilihan umum diatur dengan undangundang. 
Salah satu Pemilihan Umum yang krusial dalam ketatanegaraan Indonesia adalah Pemilihan Umum seperti halnya tercantum untuk memilih wakil rakyat yang akan duduk dalam parlemen, yang biasa dikenal dengan sebutan Pemilihan Umum Anggota Dewan Perwakilan Rakyat (DPR), Dewan Perwakilan Daerah (DPD) dan Dewan Perwakilan Rakyat Daerah tingkat Kabupaten/Kota. Ditambah lagi pada waktu bersamaan, masyarakat Indonesia harus ikut menentukan siapa yang lebih layak versi pemilihan masyarakat untuk memimpin Negara Indonesia, yakni Pemilihan Presiden dan Wakil Presiden (Pilpres). Masyarakat menyebutnya dengan Pileg dan Pilpres serentak pada waktu yang sama, sesuai dengan UndangUndang Republik Indonesia Nomor 7 tahun 2017 Tentang Pemilihan Umum.

Tindak Pidana Pemilihan Umum menurut Topo Santoso merupakan semua tindak pidana yang berkaitan dengan penyelenggaraan Pemilihan Umum yang diatur di dalam Undang-Undang Pemilihan Umum, karena fokusnya adalah tindak pidana, dengan begitu berbagai kecurangan yang terkait dengan penyelenggaraan Pemilihan Umum (Santoso, 2006). Pemilihan Umum yang dilakukan secara langsung berarti masyarakat sebagai pemilih (konstituen) memiliki hak guna memberikan hak suaranya secara langsung sesuai dengan kehendak hati nuraninya, tanpa perantara. Pemilihan yang bersifat umum mengandung makna negara menjamin semua warga negaranya tanpa diskriminasi suku, ras, agama, golongan, jenis kelamin, kedaerahan, pekerjaan dan status sosial. Setiap warga negara yang berhak memilih bebas menentukan pilihannya tanpa tekanan dan paksaan dari siapapun. Didalam melaksanakan haknya, setiap warga negara harus dijamin keamanannya oleh negara, sehingga dapat memilih sesuai dengan kehendak hati nurani. Setiap warga dalam memberikan suaranya dijamin bahwa hak pilihnya tidak akan diketahui oleh pihak manapun. Dalam penyelenggaraan Pemilihan Umum diharapkan para penyelenggara Pemilihan Umum, aparat pemerintah, peserta Pemilihan Umum, Pengawas Pemilihan Umum, pemilih, serta semua pihak yang terkait dituntut untuk bersikap dan bertindak jujur sesuai dengan peraturan perundang-undangan, setiap pemilih dan peserta Pemilihan Umum harus pula mendapatkan perlakuan sama serta bebas dari kecurangan pihak manapun. 
Interpretasinya, terjadinya kecurangan dalam Pemilihan Umum pada Pemilihan Umum serentak Tahun 2019 yang baru saja dilaksanakan merupakan sebuah fenomena yang tidak terlepas dari kepentingan para pihak dalam mewujudkan keinginannya untuk "duduk" di kursi yang diinginkan. Hal ini sangat mencederai arti dari sebuah demokrasi yang "Langsung, Umum, Bebas, dan Rahasia serta Jujur dan Adil".

Menurut Mia Amalia, menegaskan bahwa di dalam kehidupan masyarakat akan sering dijumpai perilaku-perilaku individual maupun kelompok yang menyimpang dari norma-norma yang berlaku di dalam masyarakat tersebut (Amalia, 2016). Sebagai individu maupun kelompok yang hidup bermasyarakat secara sadar maupun tidak pasti pernah melakukan perilaku menyimpang atau penyimpangan sosial. Penyimpangan sosial yang ada aka mengakibatkan terganggunya keseimbangan hidup bermasyarakat (Amalia, 2016).

Begitupun dengan penyimpangan perilaku yang dilakukan oleh sebagian pihak peserta Pemilihan Umum serentak Tahun 2019 di Kabupaten Cianjur, hal ini merupakan fenomena nyata yang semestinya mendapat perhatian semua pihak dan kalangan. Fakta di lapangan terdapat banyak permasalahan dan pelanggaran dalam penyelenggaraan Pemilihan Umum serentak pada tanggal 17 April 2019. Permasalahan Pemilih Tetap (DPT), pelanggaran kampanye, sampai dengan politik uang (money politic) menghiasi pemberiatan setiap hari. Permasalahanpermasalahan tersebut tentunya perlu adanya penyelesaian dari para pihak yang dinilai bertanggungjawab termasuk penyelesaian perkara tindak pidana Pemilihan Umum yang menjadi tanggung jawab Panitia Pengawas Pemiihan Umum dan aparat penegak hukum.

Berdasarkan Hasil wawancara dengan Bapak Hadi Zdikir Nur, Koordinator Divisi Pengawasan Humas Dan Hubal, penyelesaian perkara tindak pidana Pemilihan Umum dituntut penyelesaian secara professional. Adanya Sentra Penegakan Hukum Terpadu antara Badan/Panitia Pengawas Pemilihan Umum, Kepolisian dan Kejaksaan diharapkan mampu menangani perkara tindak pidana Pemilihan Umum serentak. Sentra Penegakan Hukum Terpadu adalah forum 
Badan Pengawas Pemlu/Panitia Pengawas Pemilu, Polri dan Kejaksaan di tiap angkatan yang dibentuk sejak Pemilihan Umum tahun 2004.

Berdasarkan Hasil Wawancara dengan Bapak Bripka Encep Rosidin, Anggota Ops Satuan Reserse dan Kriminal Kepolisian Resort Cianjur, Sentra Penegakan Hukum Terpadu ini dibentuk agar penanganan pelanggaran Pemilihan Umum lebih cepat dan tidak ada persoalan saat pelanggaran itu diserahkan dari Panitia Pengawas Pemilihan Umum kepada Kepolisian Negara Republik Indonesia.Masyarakat berharap banyak terhadap keberadaan Sentra Penegakan Hukum Terpadu ini agar pelanggaran tindak pidana Pemilihan Umum dapat ditangani secara professional. Dengan dibentuknya Sentra Penegakan Hukum Terpadu yang tersebar di seluruh tingkat Kabupaten/Kota sampai dengan tingkat pusat tentunya dengan harapan penegakan hukum tindak pidana Pemilihan Umum secara serentak dapat diselesaikan sesuai dengan prinsip peradilan yaitu cepat, sederhana dan biaya ringan serta bebas, jujur dan tidak memihak. Penilaian masyarakat terhadap fungsi Sentra Penegakan Hukum Terpadu dalam menangani perkara tindak pidana Pemilihan Umum.

Di wilayan hukum Kabupaten Cianjur, untuk perkara tindak pidana Pemilihan Umum serentah tahun 2019 yang berhasil dilimpahkan ke Pengadilan Negeri dan oleh Pengadilan Negeri dinyatakan terbukti secara sah dan meyakinkan bersalah, ada dua kasus yaitu tindak pidana politik uang (money politic) dan kasus pengrusakan Alat Peraga Kampanye. Hal-hal demikian merupakan permasalahan yang cukup krusial sehingga diperlukan pemahaman yang lebih komprehensif oleh masyarakat melalui penyuluhan-penyuluhan yang dilakukan oleh semua pihak agar proses pelaksanaan pesta demokrasi ini dapat berlangsung tanpa pelanggaran, dan tanpa mencederai arti dari "demokrasi" sebagai konsekuensi semua pihak. Dari uraian di atas, dari uraian diatas penulis tertarik untuk mengkaji : Latar Belakang berdirinya Sentra Penegakan Hukum Terpadu (Gakkumdu) dalam penanganan perkara tindak pidana Pemilihan Umum serentak Tahun 2019 di wilayah hukum Polres Cianjur; Sistem penanganan perkara tindak pidana Pemilihan Umum serentak Tahun 2019 oleh Gakkumdu dan 
Permasalahan dan upaya yang dilakukan oleh Sentra Penegakan Hukum Terpadu dalam penanganan perkara tindak pidana Pemilihan Umum serentak tahun 2019.

\section{B. METODE PENELITIAN}

Metode Penelitian yang dilakukan adalah yuridis normatif, yaitu penelitian hukum yang dilakukan dengan cara meneliti bahan pustaka (penelitian kepustakaan) atau suatu penelitian terhadap data sekunder (Soerjono Soekanto, 2001). Spesifikasi Penelitian yand digunakan adalah deskriptif analitis, yaitu suatu metode yang bermaksud guna memberikan gambaran secara menyeluruh, mengenai fakta dan permasalahan yang berhubungan dengan obyek yang diteliti, kemudian dilakukan suatu analisa terhadap permasalahan tersebut.

\section{PEMBAHASAN}

Tujuan Nasional sebagaimana ditegaskan dalam Pembukaan UndangUndang Dasar Negara Republik Indonesia Tahun 1945 diwujudkan melalui pelaksanaan penyelenggaraan negara yang berkedaulatan rakyat dan demokratis dengan mengutamakan persatuan dan kesatuan bangsa berdasarkan Pancasila dan Undang-Undang Dasar Tahun 1945.

Menurut Mia Amalia bahwa di dalam kehidupan masyarakat akan sering kita jumpai perilaku-perilaku individual maupun kelompok yang menyimpang dari norma-norma yang berlaku di dalam masyarakat tersebut. Penyimpangan yang ada akan mengakibatkan terganggunya keseimbangan hidup bermasyarakat (Amalia, 2016). Begitupun dengan tindak pidana Pemilu yang dapat dikategorikan dapat mengganggu keseimbangan hidup bermasyarakat, terutama bagi "kesehatan" masyarakat yang notabenenya dilibatkan langsung dalam berpolitik praktis.

Menurut Ahmad Hunaeni Zulkarnaen, guna terciptanya kehidupan masyarakat yang aman tertib, dan terkendali, dibutuhkan pelaksanaan peraturan hukum yang baik dan efektif, mengingat Negara Indonesia adalah Bangsa Timur walaupun faktanya konsep hukum yang berlaku adalah konsep hukum barat. Salah satu tujuan Negara Indonesia menurut Ahmad Hunaeni Zulkarnaen adalah 
"memajukan kesejahteraan umum" (alinea ke-4 Pembukaan Undang-Undang Dasar Negara Republik Indonesia Tahun 1945), Menurut Kuswandi, pada dasarnya seluruh negara di dunia memiliki tujuan yang sama yaitu diharapkan dapat memberikan kesejahteraan terhadap warga negaranya (Zulkarnaen, 2016). Menurut Henny Nuraeny bertujuan guna mengejar sebesar-besarnya kemakmuran rakyat Indonesia, yang ditujukan untuk mewujudkan kesejahteraan penduduk, menciptakan kemandirian, keadilan, serta menjunjung tinggi moral agama (Nuraeny, 2015).

Koerniatmanto Soetoprawiro dalam M. Rendi Aridhayandi menyebutkan bahwa negara ada adalah demi kesejahteraan umum. Negara berkewajiban untuk mewujudkan keseluruhan kondisi hidup kemasyarakatan, yang memungkinkan baik kelompok maupun pribadi perorangan anggota masyarakat (Aridhayandi, 2018).

Interpretasi pendapat dari para pakar hukum, menegaskan bahwa negara melalui pemerintahnya memiliki beban dan tanggung jawab dalam mensejahterakan masyarakatnya, meminimalkan kejahatan guna terselenggaranya keamanan dan ketertiban masyarakatnya, serta melaksanakan tugas dan fungsinya sebagai "abdi masyarakat".

Sejarah merupakan serangkaian kejadian pada masa lalu yang disusun berdasarkan peninggalan berbagai peristiwa. Menurut Aristoteles sejarah merupakan suatu kejadian sejak awal tersusun dalam bentuk kronologis, serta sejarah adalah peristiwa-peristiwa masa lalu yang mempunyai catatan, rekodrekod atau atau bukti-bukti yang konkrit (Wikipedia, n.d.). Berkorelasi dengan arti sejarah seperti yang telah dikemukakan di atas, sebuah tindak pidana dalam hal ini tindak pidana Pemilu memiliki sejarah yang melatarbelakangi terjadinya tindak pidana dalam Pemilu di Indonesia. Pemilu di Indonesia merupakan sarana pemenuhan demokrasi dari suatu negara, yakni perwujudan dari asas kedaulatan rakyat seperti halnya dalam rumusan Pasal 1 ayat (2) Undang-Undang Dasar Negara Kesatuan Republik Indonesia Tahun 1945. Amanat Undang-Undang Republik Indonesia Nomor 7 Tahun 2017 Tentang Pemilihan Umum bahwa Pemilu merupakan sarana pelaksanaan kedaulatan rakyat yang dilaksanakan 
secara langsung, umum, bebas, rahasia, jujur, dan adil dalam Negara Kesatuan Republik Indonesia berdasarkan Pancasila dan Undang-Undang Dasar Negara Republik Indonesia Tahun 1945. Berdasarkan hasil Wawancara dengan Bripka Dani Kusmayadi, Anggota Ops. Satuan Reserse dan Kriminal Kepolisian Resort Cianjur Namun sangat disayangkan, fakta di lapangan, banyak oknum-oknum peserta Pemilu yang mencederai proses maupun hasil dengan car acara yang bertolak belakang dengan semangat reformasi, melanggar ketentuan dan peraturan perundang-undangan yang berlaku guna kelancaran dan maksudnya untuk dapat menang dalam kontestan Pemilu.

Djoko Prakoso menyatakan bahwa tindak pidana Pemilu dalam kepustakaan adalah : secara sengaja, dengan melanggar hukum, mengacaukan, menghalanghalangi atau mengganggu jalannya Pemilihan Umum yang diselenggarakan menurut undang-undang yang dilakukan oleh orang atau badan hukum (Prakoso, 1987)."

Terjadinya tindak pidana Pemilu pada Pemilihan Umum anggota Legislatif serta Pemlihan Presiden dan Wakil Presiden Tahun 2019 di wilayah hukum Kepolisian Resort Cianjur pada umumnya dilatarbelakani kurangnya pemahaman sebagian para kontestan dan para pendukung serta simpatisan kontestan Pemilu. Selain itu, juga kurangnya edukasi yang diberikan oleh para kontestan Pemilu kepada para simpatisan dan pendukung di lapangan, sehingga terjadi pelanggaran yang mengarah pada suatu tindak pidana yang diatur dalam Undang-Undang Pemilu Tahun 2017.

Terkait dengan tindak pidana Pemilu dalam perkembangan, beberapa peraturan perundang-undangan sudah dibuat untuk mengatur hal-hal tersebut dan dalam setiap waktu diperbaharui sesuai dengan situasi dan kondisi yang dibutuhkan.

Sentra Penegakan Hukum Terpadu (Gakkumdu) hanya dioperasionalkan ketika Pemilihan Umum dilaksanakan. Gakkumdu memiliki tugas dalam menyidik segala kejahatan Pemilu yang dilaporkan melalui Panwaslu atau Bawaslu. Kedudukan Gakkumdu adalah sebagai pusat aktivitas penegakan hukum tindak pidana Pemilu yang terdiri dari unsur Badan Pengawas Pemilihan Umum, 
Kepolisian dan Kejaksaan, di mana Gakkumdu berfungsi dalam hal penanganan tindak pidana Pemilu. Sentra Penegakan Hukum Terpadu dengan tujuan guna menyamakan pemahaman dan pola penanganan tindak pidana Pemilu antara Bawaslu, Kepolisian Negara Republik Indonesia, dan Kejaksaan Agung Republik Indonesia. Fungsi Gakkumdu adalah sebagai forum koordinasi dalam proses penanganan setiap pelanggaran tindak pidana Pemilu, pelaksanaan pola tindak pidana Pemilu itu sendiri, pusat data, peningkatan kompetensi, monitoring evaluasi. Mengenai pola penanganan tindak pidana Pemilu telah dirinci dalam Standard Operational Procedure (SOP) tentang tindak pidana Pemilu pada Sentra Gakkumdu. Hal itu diharapkan dapat menciptakan Sistem Pemilihan Umum yang baik dan efektif.

\section{PENUTUP}

\section{Kesimpulan}

Berdirinya Sentra Penegakan Hukum Terpadu (Gakkumdu) dalam penanganan perkara tindak pidana Pemilihan Umum serentak Tahun 2019 di wilayah hukum Polres Cianjur, guna mengefektifkan koordinasi antara institusi yang terlibat dalam penanganan pelanggaran maupun kejahatan baik dalam tahapan maupun proses pelaksanaan Pemilu. Sentra Penegakan Hukum Terpadu Kabupaten Cianjur dalam kerangka Penegakan Hukum Pidana tindak pidana Pemilu guna memberikan kepastian hukum bagi masyarakat, baik Pemilu Legislatif maupun Pilpres sangatlah berperan serta aktif dalam menjaga kondusifitas baik jelang maupun pasca Pemilu di wilayah hukum Kepolisian Resort Cianjur.

\section{Saran}

Diharapkan ke depannya agar Sentra Penegakan Hukum Terpadu Kabupaten Cianjur dalam penanganan perkara tindak pidana Pemilihan Umum serentak di wilayah hukum Polres Cianjur lebih mengefektifkan koordinasi antara instansi yang terlibat dalam penanganan pelanggaran maupun kejahatan baik dalam tahapan maupun proses pelaksanaan Pemilu. Peningkatan kualitas personel, 
dengan evaluasi dan pelatihan; Mendayagunakan sarana dan prasarana; Sosialisasi kepada masyarakat, mengenai pentingnya kesadaran dan partisipasi masyarakat untuk melaporkan tindak pidana Pemilihan Umum. kedepannya para pihak dan semua pihak dapat mensosialisasikan regulasi yang terkait mulai dari tindak pidana, tindak pidana Pemilu dan peraturan KPU lainnya ke seluruh lapisan masyarakat. Hal ini bertujuan guna meminimalkan dan menekan angka kriminalitas terkait tindak pidana Pemilu di wilayah hukum Kepolisian Resort Cianjur.

\section{DAFTAR PUSTAKA}

Amalia, M. (2016). Perlindungan Hukum Bagi Perempuan Dan Anak Terhadap Kejahatan Seksual, dalam Jurnal Hukum Prosiding Seminar Nasional 2016 Tentang "Peran Perguruan Tinggi Dalam Memberikan Perlindungan Hukum Terhadap Perempuan Dan Anak Korban Kekerasan. Fakultas Hukum Universitas Suryakancana.

Aridhayandi, M. R. (2018). Peran Pemerintah Daerah Dalam Pelaksanaan Pemerintahan Yang Baik (Good Governance) Dibidang Pembinaan Dan Pengawasan Indikasi Geografis. Jurnal Hukum \& Pembangunan, 48(4), 883-902. http://jhp.ui.ac.id/index.php/home/article/view/1807

Mulyadi, D. (2012). Kebijakan Legislasi Tentang Sanksi Pidana Pemilu Legislatif Di Indonesia Dalam Perspektif Demokrasi. Gramata Publishing.

Nuraeny, H. (2015). Budaya Hukum Masyarakat Terhadap Fenomena Terhadap Pengiriman Tenaga Kerja Migran Sebagai Salah Satu Bentuk Perbudakan Modern Dari Tindak Pidana Perdagangan Orang. Jurnal Hukum Dan Peradilan, 4(3), 501-508. https://www.jurnalhukumdanperadilan.org/index.php/jurnalhukumperadilan/ article/view/59

Prakoso, D. (1987). Tindak Pidana Pemilu. Sinar Harapan.

Santoso, T. (2006). Tindak Pidana Pemilu. Sinar Grafika.

Soerjono Soekanto, S. M. (2001). Penelitian Hukum Normatif. PT. Raja Grafindo Persada.

Wikipedia. (n.d.). sejarah. http://id.wikipedia.org/wiki/Sejarah

Zulkarnaen, A. H. (2016). Cita Hukum Positif Indonesia dan Asean Economic Community (AEC). Jurnal Hukum Mimbar Justitia, 2(1), 709-724. https://jurnal.unsur.ac.id/jmj/issue/view/8 